\title{
PENERAPAN PROGRAM ADIWIYATA DI SMP NEGERI 13 PALEMBANG
}

\author{
${ }^{1}$ Kania Sitisyarah dan ${ }^{2}$ Ramadhanita Mustika \\ ${ }^{1}$ Guru SMP Negeri 13 Kota Palembang \\ ${ }^{2}$ Dosen Program Pascasarjana Universitas PGRI Palembang \\ e-mail: kaniasitisyarah@ymail.com
}

\begin{abstract}
This research was qualitative, which describes the application of Adiwiyata program at State Secondary School 13 Palembang. The instruments used in this research were interview, observation and previous finding and theories related to the characteristics of Adiwiyata school. Based on the analysis, the application of Adiwiyata program at State Secondary School 13 Palembang were environmentally sound policy, the implementation of environment based curriculum, participative environment based activities, management of friendly environment which support facilities. As Adiwiyata School, State Secondary School 13 Palembang has achieved a series of achievements, such in May 2013, this State Secondary School won the I Adiwiyata (school environmental level) city level. In June of the same year, State Secondary School 13 Palembang being the winner of Adiwiyata (provincial-level of environmental school). Then, in December 2013, State Secondary School 13 Palembang returned to achievement by winning I Adiwiyata (environmentally sound schools) at the national level. In 2015, this State Secondary School won the I Adiwiyata (environmentally independent school) with 17 schools. After successfully becoming an independent Adiwiyata school, State Secondary School 13 Palembang is currently heading to ECOASEAN Adiwiyata School by creating environmental innovation from plastic waste.
\end{abstract}

Keywords: Adiwiyata, ECOASEAN, State Secondary School 13 Palembang

\section{PENDAHULUAN}

Lingkungan hidup merupakan bagian yang tidak terpisahkan dari makhluk hidup. Berdasarkan Undang-Undang Republik Indonesia Nomor 23 Tahun 1997 tentang Pengelolaan Lingkungan Hidup, Lingkungan hidup adalah kesatuan ruang dengan semua benda, daya, keadaan, dan makhluk hidup, termasuk manusia dan perilakunya, yang mempengaruhi kelangsungan perikehidupan dan kesejahteraan manusia serta makhluk hidup lain.

Pendidikan Lingkungan Hidup (PLH) merupakan program pendidikan untuk membina siswa supaya memiliki pengertian, kesadaran, sikap, perilaku yang rasional serta bertanggung jawab terhadap alam dan terlaksanakannya pembangunan yang berkelanjutan melalui program sekolah yang biasa disebut dengan program Adiwiyata. Menurut Peraturan Menteri Lingkungan Hidup Republik Indonesia Nomor 05 Tahun 2013 tentang Pedoman Pelaksanaan Program Adiwiyata, sekolah adiwiyata merupakan sekolah yang peduli dan berbudaya lingkungan.

Dalam mewujudkan sekolah yang peduli dan berbudaya lingkungan perlu didukung 
sarana dan prasarana yang mencerminkan upaya pengelolaan lingkungan hidup. Lingkungan Sekolah yang kondusif sangat diperlukan agar tercipta proses pembelajaran yang bermutu. Pemberian pengetahuan dan pembentukan kesadaran tentang perilaku hidup bersih dan sehat dirasa sangat efektif ketika dilakukan pada siswa sejak dini. Sekolah yang berbudaya lingkungan sebagai salah satu wadah peningkatan pengetahuan dan kemampuan siswa memiliki peran penting dalam menyumbang perubahan yang terjadi dalam keluarga. Bagaimana menghargai air bersih, memahami pentingnya penghijauan, memanfaatkan fasilitas sanitasi secara tepat serta mengelola sampah menjadi pupuk tidak terpisahkan dalam upaya peningkatan perilaku hidup bersih dan sehat.

Program adiwiyata memiliki beberapa komponen. Komponen-komponen tersebut mendukung terlaksananya sekolah yang peduli dan berwawasan lingkungan. Menurut Peraturan Menteri Lingkungan Hidup Republik Indonesia Nomor 05 Tahun 2013 Pasal 6 Ayat 1 tentang Pedoman Pelaksanaan Program Adiwiyata, komponen program adiwiyata, meliputi: (a) Aspek kebijakan sekolah yang berwawasan lingkungan; (b) Aspek kurikulum sekolah berbasis lingkungan; (c) Aspek kegiatan sekolah berbasis partisipatif; dan (d) Aspek pengelolaan sarana dan prasarana pendukung sekolah yang ramah lingkungan.

Salah satu sekolah yang peduli dan berbudaya lingkungan di kota Palembang adalah SMP Negeri 13 Palembang. Seperti yang tercantum dalam visi yaitu "Menjadikan SMP Negeri 13 Palembang sekolah yang Berilmu, Berakhlaq mulia, Berbudaya dan Berwawasan lingkungan" serta salah satu misinya yaitu "Menciptakan sekolah yang Bersih, Aman, Rapi dan Indah". Dalam pelaksanaanya, sekolah ini telah menerapkan berbagai kebijakan yang berwawasan lingkungan untuk mendukung program adiwiyata. Salah satu contohnya yaitu dengan mewajibkan siswa untuk membawa tanaman apabila melakukan pelanggaran.

\section{PENDIDIKAN LINGKUNGAN HIDUP}

Berdasarkan Undang-Undang Republik Indonesia Nomor 23 Tahun 1997 tentang Pengelolaan Lingkungan Hidup, "Lingkungan hidup adalah kesatuan ruang dengan semua benda, daya, keadaan, dan makhluk hidup, termasuk manusia dan perilakunya, yang mempengaruhi kelangsungan peri kehidupan dan kesejahteraan manusia serta makhluk hidup lain”. Manusia dan lingkungan memiliki hubungan yang erat. Kelangsungan hidup manusia sangat tergantung pada alam, demikian pula sebaliknya. Oleh karena itu, sudah sepatutnya manusia menjaga kelestarian lingkungannya. Dengan demikian, diperlukan 
Pendidikan Lingkungan Hidup sejak dini agar manusia dapat memperlakukan lingkungannya dengan baik. Termasuk dalam mendukung berjalannya pembangunan yang sejalan dengan kelestarian lingkungan.

Yusuf (1994) mengatakan bahwa Pendidikan Lingkungan Hidup adalah proses pengembangan apresiasi akan saling ketergantungan antara manusia dengan biofisik dan binaannya sehingga muncul sikap dan nilai mau memelihara keselarasan hubungan antara komponen-komponen lingkungan hidup. Pendidikan Lingkungan Hidup juga mampu menimbulkan kepekaan manusia terhadap permasalahan lingkungan sekitarnya. Senada dengan hal itu, menurut Soeriatmadja (1997), Pendidikan Lingkungan Hidup merupakan suatu proses yang bertujuan untuk mengembangkan kesadaran umat manusia akan lingkungan hidup dengan seluruh permasalahan yang ada di dalamnya.

\section{ADIWIYATA}

Adiwiyata merupakan program yang dijalankan dalam dunia pendidikan untuk meningkatkan kesadaran terhadap pentingnya kelestarian lingkungan. Berbagai ilmu pengetahuan dan norma lebih mudah dipelajari dan diterapkan dalam dunia pendidikan. Oleh karena itu, adiwiyata diterapkan dalam dunia pendidikan. Dalam Peraturan Menteri Lingkungan Hidup Republik Indonesia Pasal 1
Ayat 1 Nomor 05 Tahun 2013 tentang Pedoman Pelaksanaan Program Adiwiyata dijelaskan bahwa "sekolah adiwiyata adalah sekolah yang peduli dan berbudaya lingkungan." Senada dengan hal itu, dalam Peraturan Menteri Lingkungan Hidup Republik Indonesia pasal 1 ayat 2 Nomor 05 Tahun 2013 tentang Pedoman Pelaksanaan Program Adiwiyata mengungkapkan bahwa program Adiwiyata adalah program untuk mewujudkan sekolah yang peduli dan berbudaya lingkungan.

Sekolah adiwiyata menjadi tempat yang efektif untuk membina kepekaan siswa terhadap permasalahan yang terjadi di lingkungan hidup dengan diterapkannya Pendidikan Lingkungan Hidup. Menurut Peraturan Menteri Negara Lingkungan Hidup Nomor 02 Tahun 2009 tentang Pedoman Pelaksanaan Program Adiwiyata, "Adiwiyata adalah sekolah yang baik dan ideal sebagai tempat memperoleh segala ilmu pengetahuan dan berbagai norma serta etika yang dapat menjadi dasar manusia menuju terciptanya kesejahteraan hidup dan cita-cita pembangunan berkelanjutan." Berdasakan Peraturan Menteri Negara Lingkungan Hidup Nomor 02 Tahun 2009 tentang Pedoman Pelaksanaan Program Adiwiyata, Program Adiwiyata adalah salah satu program kerja berlingkup nasional yang dikelola oleh Kementerian Negara Lingkungan Hidup dalam 
rangka mewujudkan pengembangan pendidikan lingkungan hidup. Dalam pelaksanaannya, program adiwiyata diiukuti oleh berbagai jenjang pendidikan. Hal ini tertera dalam Peraturan Menteri Lingkungan Hidup Republik Indonesia pasal 4 ayat 1 dan 2 Nomor 05 Tahun 2013 tentang Pedoman Pelaksanaan Program Adiwiyata sebagai berikut: (1) Program Adiwiyata diikuti oleh: a. Sekolah Dasar (SD) atau Madrasah Ibtidaiyah (MI); b. Sekolah Menengah Pertama (SMP) atau Madrasah Tsanawiyah (MTs); c. Sekolah Menengah Atas (SMA) atau MadrasahAliyah (MA); dan d. Sekolah Menengah Kejuruan (SMK) atau Madrasah Aliyah Kejuruan (MAK). (2) Sekolah atau madrasah sebagaimana dimaksud pada ayat (1) berstatus negeri atau swasta yang telah terakreditasi.

Tim Adiwiyata Tingkat Nasional (2012: 3) mengungkapkan bahwa tujuan program adiwiyata adalah mewujudkan warga sekolah yang bertanggung jawab dalam upaya perlindungan dan pengelolaan lingkungan hidup melalui tata kelola sekolah yang baik untuk mendukung pembangunan berkelanjutan.

Pelaksanaan Adiwiyata di sekolah memiliki banyak dampak positif. Tim Adiwiyata Nasional (2011:4) mengungkapkan beberapa keuntungan mengikuti Program Adiwiyata sebagai berikut: (1) Mendukung tercpainya standar kompetensi/kompetensi dasar dan standar kompetensi lulusan (SKL) pendidikan dasar dan menengah,
Meningkatkan efesiensi penggunaan dana operasional sekolah melalui penghematan dan pengurangan konsumsi dari berbagai sumber daya dan energy, (3) Menciptakan kebersamaan warga sekolah dan kondisi belajar mengajar yang lebih nyaman dan kondusif, (4) Menjadi tempat pembelajaran tentang nilai-nilai pemeliharaan dan pengelolaan lingkungan hidup yang baik dan benar bagi warga sekolah dan masyarakat sekitar, (5) Meningkatkan upaya perlindungan dan pengelolaan lingkungan hidup melalui kegiatan pengendalian.

Setiap komponen yang terkandung dalam sekolah adiwiyata menjadi faktor pendukung penting dalam pelaksanaan program adiwiyata. Komponen-komponen ini juga merupakan kriteria yang harus dimiliki oleh sekolah adiwiyata. Dalam pelaksaannya diperlukan kerja sama berbagai pihak demi tercapainya tujuan yang diharapkan. Adapun komponen beserta standar yang terkandung dalam adiwiyata berdasarkan Peraturan Menteri Lingkungan Hidup Republik Indonesia Nomor 05 Tahun 2013 Tentang Pedoman Pelaksanaan Program Adiwiyata sebagai berikut (1) Kebijakan berwawasan lingkungan, memiliki standar, (2) Pelaksanaan kurikulum berbasis lingkungan, memiliki standar, (3) Kegiatan lingkungan berbasis partisipatif memiliki standar, (4) Pengelolaan 
sarana pendukung ramah lingkungan memiliki standar.

Ada beberapa jenis dan bentuk penghargaan dalam program adiwiyata antara lain (1) Sekolah adiwiyata kabupaten/ kota mendapat penghargaan dari bupati/ wali kota.

Bentuk penghargaan berupa piagam dan piala, (2) Sekolah adiwiyata propinsi mendapat penghargaan dari gubernur bentuk penghargaan berupa piagam dan piala, (3) Sekolah adiwiyata nasional mendapatkan penghargaan dan piala dari menteri lingkungan hidup dan menteri pendidikan dan kebudayaan. (4) Sekolah adiwiyata mandiri mendapatkan penghargaan piagam dari menteri linkungan hidup dan menteri pendidikan dan kebudayaan dan piala dari menteri linkungan hidup, dan diserahkan oleh presiden.

Langkah-langkah untuk menciptakan sekolah adiwiyata adalah sebagai berikut: (1) Recycle atau mendaur ulang, adalah kegiatan mengolah kembali. Pada prinsipnya, kegiatan ini memanfaatkan barang bekas dengan cara mengolah materinya untuk dapat digunakan lebih lanjut. Contohnya adalah memanfaatkan dan mengolah sampah organik untuk dijadikan pupuk kompos, (2) Reuse atau penggunaan kembali, adalah kegiatan menggunakan kembali material atau bahan yang masih layak pakai. Sebagai contoh, kantong plastik atau kantong kertas yang umumnya didapat dari hasil kita berbelanja, sebaiknya tidak dibuang tetapi dikumpulkan untuk digunakan kembali saat dibutuhkan. Contohnya adalah menggunakan baterai isi ulang, (3) Reduce atau pengurangan, adalah kegiatan mengurangi pemakaian atau pola perilaku yang dapat mengurangi produksi sampah serta tidak melakukan pola konsumsi yang berlebihan. Contohnya ialah menggunakan alat-alat makan atau dapur yang tahan lama dan berkualitas sehingga memperpanjang masa pakai produk atau mengisi ulang atau refill produk yang dipakai seperti aqua galon, tinta printer serta bahan rumah tangga seperti deterjen, sabun, minyak goreng, dan lainnya. Hal ini dilakukan untuk mengurangi potensi bertumpuknya sampah wadah produk di rumah, (4) Replace atau penggantian, adalah kegiatan untuk mengganti pemakaian suatu barang atau memakai barang alternatif yang sifatnya lebih ramah lingkungan dan dapat digunakan kembali. Upaya ini dinilai dapat mengubah kebiasaan seseorang yang mempercepat produksi sampah. Contohnya mengubah menggunakan kantong plastik atau kertas belanjaan dengan membawa tas belanja sendiri yang terbuat dari kain, (5) Replant atau penanaman kembali, adalah kegiatan melakukan penanaman kembali. Contohnya melakukan kegiatan kreatif seperti membuat pupuk kompos dan berkebun di pekarangan 
rumah. Dengan menanam beberapa pohon, lingkungan akan menjadi indah dan asri, membantu pengauran suhu pada tingkat lingkungan mikro (sekitar rumah), dan mengurangi kontribusi atas pemanasan global.

Pengolahan lingkungan sekolah dapat dilakukan melalui peningkatan pengetahuan dan kemampuan siswa dalam pengelolaan air, pengelolaan sampah, pengelolaan energi dan halaman yang ada di sekitar sekolah.

\section{Pengelolaan Air di Sekolah}

Ketersediaan air bersih disekolah sangat diperlukan dalam jumlah yang relatif banyak. Hal ini mengingat jumlah warga sekolah yang terdiri dari siswa, guru, dan karyawan dapat mencapai ratusan orang. Sehinga kebutuhan air bersih akan lebih banyak lagi. Jenis kebutuhan air disekolah adalah untuk minum, membersihkan lantai, membersihkan WC, mencuci peralatan laboratorium dan menyiram tanaman. Sumber air bersih yang digunakan bagi pemenuhan kebutuhan warga sekolah dapat berasal dari air PDAM. Selain itu untuk menciptakan suatu kondisi sekolah yang sehat, sekolah harus memenuhi kriteria, antara lain kebersihan dan ventilasi ruangan, kebersihan kantin, WC, kamar mandi, tempat cuci tangan, melaksanakan pelayanan kesehatan, pendidikan kesehatan, bimbingan konseling dan manajemen peran serta masyarakat. Sekolah-sekolah yang berada di negara-negara maju umumnya sudah memiliki teknologi pengelolaan air limbah. Sehingga air bersih yang tersedia untuk memenuhi kebutuhan sekolah tidak berasal dari sumbernya, akan tetapi menggunakan kembali air yang sudah dipakai melalui teknologi air limbah.

2. Pengelolaan Sampah di Sekolah

Agar pengelolaan sampah berlangsung dengan baik dan mencapai tujuan yang diinginkan, maka setiap kegiatan pengelolaan sampah harus mengikuti cara-cara yang baik dan benar. Apa pentingnya pengelolaan sampah disekolah ? Pada prinsipnya semakin sedikit dan semakin dekat sampah dikelola dari sumbernya, maka pengelolaannya akan semakin mudah dan baik, serta lingkungan yang terkena dampak juga semakin sedikit. Tahapan-tahapan pengelolaan sampah di sekolah adalah (1) Pencegahan dan pengurangan sampah dari sumbernya. Kegiatan ini dimulai dengan kegiatan pemilahan atau pemisahan organik dan anorganik dengan menyediakan tempat sampah organik dan anorganik disetiap kawasan sekolah. (2). Pemanfaatan kembali sampah terdiri atas: Pemanfaatan sampah organik, seperti komposting (pengomposan) sampah yang mudah membusuk dapat diubah manjadi pupuk kompos yang ramah lingkungan untuk melestarikan fungsi kawasan sekolah. Berdasarkan hasil penelitian bahwa dengan melakukan kegiatan composting 
sampah organik yang komposisinya mencapai $70 \%$ dapat direduksi hingga mencapai $25 \%$. Pemanfaatan sampah anorganik, baik secara langsung maupun tidak langsung. Pemanfaatan kembali secara langsung, misalnya pembuatan kerajinan yang berbahan baku dari barang bekas, atau kertas daur ulang. Sedangkan pemanfaatan kembali secara tidak langsung, misalnya menjual barang bekas seperti kertas, plastic, kaleng, koran bekas, botol, gelas dan botol air minum dalam kemasan. Tempat pembuangan sampah akhir. Sisa sampah yang tidak dapat dimanfaatkan secara ekonomis baik dari kegiatan komposting maupun pemanfaatan sampah anorganik, jumlahnya mencapai $\pm 10 \%$ harus dibuang ke tempat pembuangan sampah akhir (TPA) di sekolah.

\section{Pengelolaan Energi di Sekolah}

Penggunaan energi di sekolah sangat penting agar proses pembelajaran dapat berjalan dengan baik. Penggunaan energi di sekolah biasanya untuk menerangi ruanganruangan, menyalakan barang-barang elektronik seperti komputer dan media pembelajaran, mengalirkan pompa air dll. Terhadap fasilitas umum seperti sekolah, hendaknya kita bersama-sama bertanggung jawab untuk memelihara dan menghemat pada saat pemakaiannya. Banyak cara yang dapat kalian lakukan dalam rangka pengelolaan energi disekolah, misalnya melalui penggunaan cahaya matahari untuk menerangi ruangan- ruangan belajar di kelas, perpustakaan, laboratorium, dll. Menghemat pemakaian air karena dialirkan menggunakan listrik, mematikan lampu-lampu yang masih menyala saat siang hari. Mematikan alat-alat elektronik seperti komputer dan televisi saat sedang tidak digunakan.

\section{Pengelolaan Halaman Sekolah}

Sekolah sebagai tempat belajar perlu memiliki lingkungan yang bersih dan sehat agar tercipta suasana belajar yang nyaman. Halaman sekolah selain di tata keindahannya, juga perlu memperhatikan persyaratan kesehatan. Halaman sekolah yang tidak sehat dapat menimbulkan berbagai macam penyakit sehingga menimbulkan rasa tidak nyaman bagi semua warga sekolah.

Penelitian ini membahas penerapan program adiwiyata di SMPN 13 Palembang. Penelitian mengenai sekolah adiwiyata pernah dilakukan sebelumnya oleh Hidayati (2013) yakni berjudul Perilaku Warga Sekolah dalam Program Adiwiyata di SMK Negeri 2 Semarang. Penelitian ini menunjukkan bahwa keberhasilan Adiwiyata di SMK Negeri 2 Semarang didukung oleh seluruh warga sekolah. Selain itu, penelitian serupa juga dilakukan oleh Reni Indriwati yaitu berjudul Implementasi Pendidikan Karakter pada Program Adiwiyata melalui Kegitan Lingkungan Berbasis Partisipatif di Smk Negeri 1 Turen. Penelitian ini menunjukkan 
bahwa penanaman nilai pendidikan karakter dilakukan atau diterapkan melalui keikutsertaan siswa dalam menjalankan berbagai kegiatan partsispatif yang direncanakan oleh sekolah. Adapun persamaan penelitian ini dengan penelitian sebelumnya yaitu membahas program adiwiyata dalam pelaksanaannya di sekolah. Namun, penelitian ini lebih menekankan pada komponenkomponen pendukung adiwiyata di SMPN 13 Palembang.

\section{METODE PENELITIAN}

Adapun jenis penelitian yang digunakan dalam mendeskripsikan penerapan program adiwiyata di SMPN 13 Palembang adalah penelitian kualitatif. Penelitian kualitatif merupakan sebuah prosedur penelitian yang menghasilkan data deskriptif yang berbentuk tulisan tentang orang atau kata-kata orang dan perilakunya yang tampak atau kelihatan (Harsono, 2011:33). Dalam penelitian kualitatif, seorang peneliti dimungkinkan untuk secara lebih mendalam dapat mengeksplorasi konsep-konsep yang pada dasarnya diabaikan dalam penelitian atau pendekatan lain. Sugiyono (2011:268) mengatakan dalam penelitian kualitatif, temuan atau data dapat dinyatakan valid apabila tidak ada perbedaan antara yang dilaporkan peneliti dengan apa yang sesungguhnya terjadi pada objek yang diteliti.
Objek pada penelitian ini adalah SMP Negeri 13 Palembang. Menurut Sugiyono (2009:49) populasi dalam penelitian kualitatif dinamakan "social situation" yang terdiri atas tiga elemen yaitu: tempat (place), pelaku (actors), dan aktivitas (activity) yang berinteraksi secara sinergis. Ketiga elemen tersebut yang dijadikan sebagai objek penelitian untuk mengetahui peristiwa apa yang terjadi di dalamnya untuk mencapai tujuan penelitian.

Metode pengumpulan data yang digunakan dalam penelitian ini adalah wawancara, observasi dan studi hasil penelitian dan teori-teori terkait karakteristik sekolah Adiwiyata. Observasi merupakan salah satu teknik pengumpulan data yang digunakan dalam penelitian kualitatif (Emzir, 2011). Menurut Sutrisno (2004), sebagai metode ilmiah, observasi biasanya diartikan sebagai pengamatan dan pencatatan dengan sistematis atas fenomena-fenomena yang diteliti. Kemudian teknik studi dokumen yang digunakan adalah mencari data mengenai halhal yang berupa catatan, transkip, buku, surat kabar, majalah, prasasti, notulen rapat, legger, dan agenda (Arikunto, 2002). Hadari (2005) menyatakan bahwa studi dokumen adalah "cara pengumpulan data melalui peninggalan tertulis terutama berupa arsip-arsip dan termasuk juga buku mengenai pendapat, dalil 
yang berhubungan dengan masalah penyelidikan".

Dalam menganalisis data, peneliti menggunakan analisis data dengan model interaktif menurut Miles dan Huberman yang dikutip oleh Sugiyono (2012:246) yaitu melalui tahap reduksi data, penyajian data, dan penarikan kesimpulan.

\section{HASIL PENELITIAN DAN PEMBAHASAN}

Berdasarkan hasil analisis, maka penerapan program adiwiyata di SMPN 13 Palembang dapat dilihat berdasarkan penerapan komponen adiwiyata yaitu, kebijakan berwawasan lingkungan, pelaksanaan kurikulum berbasis lingkungan, kegiatan lingkungan berbasis partisipatif, pengelolaan sarana pendukung ramah lingkungan.

Karakteristik kebijakan berwawasan lingkungan di SMPN 13 Palembang dapat dilihat berdasarkan (1) visi dan misi sekolah: visi SMPN 13 Palembang yaitu "Menjadikan SMP Negeri 13 Palembang sekolah yang Berilmu, Berakhlaq mulia, Berbudaya dan Berwawasan lingkungan" dengan misi "Menciptakan sekolah yang Bersih, Aman, Rapi dan Indah", (2) struktur kurikulum memuat mata pelajaran muatan lokal terkait kebijakan perlindungan dan pengelolaan lingkungan hidup : siswa dibimbing membuat tanamaan hidroponik oleh guru prakarya. Hal ini sesuai dengan salah satu prinsip adiwiyata yang berkelanjutan yakni seluruh kegiatan harus dilakukan secara terencana dan terus menerus secara komprehensif. Kebijakan berwawasan lingkungan yang terdapat dalam visi dan misi sekolah menunjukkan bahwa seluruh warga SMPN 13 Palembang memiliki kepedulian terhadap lingkungan dan memiliki tekad yang kuat terhadap kelestarian lingkungan. Adanya pembuatan tanaman hidroponik dalam pembelajaran IPA tidak hanya membuat siswa menjadi kreatif, tetapi juga turut membantu kelestarian lingkungan.

Katakteristik pelaksanaan kurikulum berbasis lingkungan di SMP Negeri 13 Palembang antara lain (1) mengembangkan isu lokal dan atau isu global sebagai materi pembelajaran LH sesuai dengan jenjang pendidikan mengadakan penghijauan dengan cara membuat tanaman hidroponik di bawah bimbingan guru IPA, (2) menghasilkan karya nyata yang berkaitan dengan pelestarian fungsi LH, mencegah terjadinya pencemaran dan kerusakan LH: memanfaatkan botol bekas menjadi pot tanaman yang kemudian digantung di dinding-dinding sekolah, menciptakan tong sampah basah dan kering dari ember kemudian dihias dengan cara dilukis, dan melakukan penghijauan dengan cara membuat tanaman hidroponik, (3) menerapkan pengetahuan LH yang diperoleh untuk memecahkan masalah LH dalam 
kehidupan sehari-hari: setiap warga sekolah diharuskan membawa kotak makanan sendiri dari rumah sebab di sekolah tidak diperbolehkan menggunakan kantong plastik, apabila melakukan pelanggaran, siswa dihukum untuk membawa tanaman berukuran besar. Mengadakan penghijauan merupakan salah satu cara yang baik untuk membuat siswa memahami sekaligus melakukan tindakan nyata untuk mengurangi pemanasan global. Selain itu, menciptakan karya dari bahan daur ulang merupakan cara yang efektif untuk membuat siswa memahami bahwa sampah yang mereka hasilkan bisa menjadi barang yang berguna jika dikelola dengan baik. Pemberian hukuman yang berhubungan dengan pelestarian lingkungan merupakan cara yang baik dalam mendidik siswa, disediakan tempat akhir pembuangan sampah di bagian sekolah. Disediakan juga air bersih dan fasilitas lain untuk digunakan oleh seluruh warga sekolah.

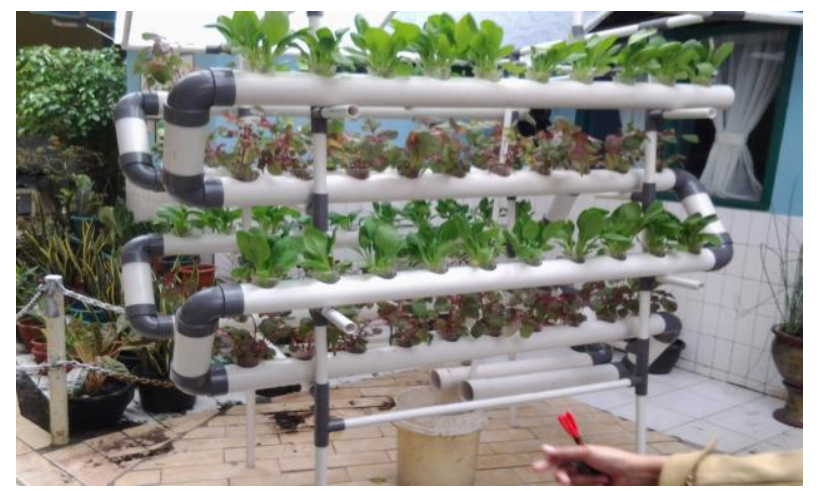

Gambar. Tanaman Hidroponik

Karakteristik kegiatan lingkungan berbasis partisipatif di SMPN 13 Palembang yaitu (1) memelihara dan merawat gedung dan lingkungan sekolah oleh warga sekolah : seluruh warga sekolah wajib merawat gedung sekolah dan setiap kelas diberikan jadwal piket untuk membersihkan halaman sekolah atas pengawasan guru piket, misalnya di hari Senin kelas 9.1 membersihkan halaman depan dan belakang sekolah, sementara kelas 8.1 membersihkan halaman samping kanan dan kir i sekolah, (2) memanfaatkan lahan dan fasilitas sekolah sesuai kaidah- kaidah perlindungan dan pengelolaan LH (dampak yang diakibatkan oleh aktivitas sekolah): pemeliharaan taman, pengelolaan sampa organik dan anorganik, (3) adanya kreativitas dan inovasi warga sekolah dalam upaya perlindungan dan pengelolaan lingkungan hidup: menciptakan inovasi lingkungan dari sampah plastik, (4) memberi dukungan untuk meningkatkan upaya perlindungan dan pengelolaan LH : pengelolaan sampah dan menciptakan tanaman hidroponik. Programprogram tersebut dapat terlaksana berkat kerjasama seluruh warga sekolah. Hal ini sesuai dengan prinsip adiwiyata, yaitu partisipatif. Dalam pemeliharaan gedung sekolah dan pelaksanaan piket di lingkungan sekolah, baik siswa dan guru turut berperan aktif demi tercapainya lingkungan sekolah yang bersih, aman, rapi dan indah. Selain itu, setiap individu dilatih untuk memiliki kesadaran dalam pemeliharaan dan 
pengelolaan lingkungan., (5) Setiap selesai jam istirahat dan jam pulang sekolah, duta cinta lingkungan (ducil) mengecek kebersihan tiap-tiap kelas. Mulai dari sampah yang berserakan di lantai, laci meja, dan depan ruang kelas, (6) siswa dibimbing oleh guru untuk mendaur ulang daun kering menjadi pupuk kompos dan melakukan pembibitan tanaman di sekitar sekolah. Hal ini dilakukan agar sampah yang berupa daun kering dapat dimanfaatkan dengan baik. Siswa juga dibimbing untuk membuang sampah plastik/botol air mineral dalam bak sampah khusus yang sudah disediakan. Gunanya adalah supaya guru dan siswa tidak lagi harus memisahkan sampah-sampah tersebut. Bahkan, sampah plastik/botol air mineral dapat dibuat menjadi wadah tanaman hidroponik ataupun dapat dijual.

\section{Karakteristik pengelolaan sarana} pendukung ramah lingkungan di SMPN 13 Palembang meliputi (1) menyediakan sarana prasarana untuk mengatasi permasalahan lingkungan hidup di sekolah: penyediaan tempat sampah terpisah antara sampah organik dan anorganik yang terbuat dari ember cat bekas, (2) memelihara sarana dan prasarana sekolah yang ramah lingkungan: mengadakan penghijauan, (3) meningkatkan kualitas pelayanan kantin sehat dan ramah lingkungan : kantin sekolah tidak menjual makanan dengan menggunakan kantong plastik, tetapi siswa membawa sendiri kotak makanan dari rumah. Cara ini sangat efektif digunakan untuk mengurangi sampah plastik di sekolah. Berdasarkan karakteristik tersebut, dapat diketahui bahwa siswa dilatih untuk menciptakan sendiri sarana penunjang kelestarian lingkungannya dari bahan daur ulang. Dengan demikian, disamping melatih kreativitas siswa, kegiatan ini juga mampu mengatasi masalah lingkungan. Selain itu, adanya kantin sehat yang tidak menggunakan kantong plastik, sangat efektif untuk mengurangi sampah.

Sebagai sekolah adiwiyata, SMPN 13 Palembang telah meraih sederet prestasi, yaitu pada bulan Mei 2013, SMP ini telah meraih juara I adiwiyata (sekolah berwawasan lingkungan) tingkat kota yang dibina oleh SMA 17 Plus Palembang. Pada bulan Juni di tahun yang sama, SMPN 13 Palembang berhasil meraih juara I adiwiyata (sekolah berwawasan lingkungan) tingkat provinsi dengan membina 16 sekolah. Kemudian, pada Desember 2013, SMPN 13 Palembang kembali berprestasi dengan meraih juara I adiwiyata (sekolah berwawasan lingkungan) di tingkat nasional. Pada tahun 2015, SMP ini berhasil meraih juara I adiwiyata (sekolah berwawasan lingkungan) mandiri dengan membina 17 sekolah. Setelah berhasil menjadi sekolah adiwiyata mandiri, SMPN 13 Palembang saat ini sedang menuju sekolah 
adiwiyata ECOASEAN dengan menciptakan inovasi lingkungan dari sampah plastik.

\section{KESIMPULAN}

Penerapan program adiwiyata dapat dilihat berdasarkan komponen-komponen adiwiyata. Karakteristik kebijakan berwawasan lingkungan dapat dilihat berdasarkan (1) visi dan misi sekolah, (2) struktur kurikulum memuat mata pelajaran muatan lokal terkait kebijakan perlindungan dan pengelolaan lingkungan hidup.

Karakteristik pelaksanaan kurikulum berbasis lingkungan di SMPN 13 Palembang meliputi (1) mengembangkan isu lokal dan atau isu global sebagai materi pembelajaran LH sesuai dengan jenjang pendidikan, menghasilakan karya nyata yang berkaitan dengan pelestarian fungsi $\mathrm{LH}$, mencegah terjadinya pencemaran dan kerusakan LH. Karakteristik kegiatan lingkungan berbasis partisipatif di SMPN 13 Palembang yaitu (1) memelihara dan merawat gedung dan lingkungan sekolah oleh warga sekolah, (2) memanfaatkan lahan dan fasilitas sekolah sesuai kaidah-kaidah perlindungan dan pengelolaan LH (dampak yang diakibatkan oleh aktivitas sekolah), (3)adanya kreativitas dan inovasi warga sekolah dalam upaya perlindungan dan pengelolaan lingkungan hidup, (4) memberi dukungan untuk meningkatkan upaya perlindungan dan pengelolaan LH. Karakteristik pengelolaan sarana pendukung ramah lingkungan di SMPN 13 Palembang antara lain, (1) menyediakan sarana prasarana untuk mengatasi permasalahan lingkungan hidup di sekolah, (2) memelihara sarana dan prasarana sekolah yang ramah lingkungan, (3) meningkatkan kualitas pelayanan kantin sehat dan ramah lingkungan.

\section{DAFTAR PUSTAKA}

Arikunto, Suharsimi. (2002). Prosedur Penelitian, Suatu Pendekatan Praktik. Jakarta: PT. Rineka Cipta.

Chaniago, Amelia. (2013). Menggagas Sekolah Berwawasan Lingkungan. http://lingkunganadiwiyata.blogspot.co.i d/, diakses pada tanggal 7 Januari 2017.

Dapodiknews. (2013). 5 Langkah Untuk Menciptakan Sekolah Berwawasan Adiwiyata yang Mudah Dilakukan. http://dapodiknews.blogspot.com/2015/0 3/5-langkah- menciptakan-sekolah.html, diakses pada tanggal 7 Januari 2017.

Emzir. (2011). Analisis Data: Metodologi Penelitian Kualitatif. Jakarta: Rajawali Press.

Harsono. (2011). Etnografi Pendidikan sebagai Desain Penelitian Kualitatif. Surakarta: Universitas Muhammadiyah Surakarta.

Kementerian Negera Lingkungan Hidup. (2009). Wujud Sekolah Perduli dan Berbudaya Lingkungan dilengkapai Panduan Materi Pendidikan Lingkungan Hidup. Jakarta: Badan Lingkungan Hidup Jawa Timur. 12) 
Peraturan Menteri Lingkungan Hidup Republik Indonesia Nomor 05 Tahun 2013 tentang Pedoman Pelaksanaan Program Adiwiyata. Jakarta: Menteri Lingkungan Hidup Republik Indonesia.

Peraturan Menteri Negara Lingkungan Hidup Nomor 02 Tahun 2009 tentang Pedoman Pelaksanaan Program Adiwiyata. Jakarta: Menteri Negara Lingkungan Hidup.

Soeriaatmadja.1997. Ilmu Lingkungan. Bandung : ITB.

Soerjani, Mohamad. 2009. Pendidikan Lingkungan Sebagai Dasar Kearifan Sikap dan

Perilaku Bagi Kelangsungan Kehidupan Menuju Pembangunan Berkelanjutan. Universitas Indonesia (UI-Press)

Sugiyono. (2009). Memahami Penelitian Kualitatif. Bandung: Alfabeta

Sugiyono. (2011). Metode Penelitian Pendidikan. Bandung: Alfabeta.
Sugiyono. (2012). Metode Penelitian Kuantitatif Kualitatif dan $R \& D$. Bandung, Alfabeta.

Sutrisno, Hadi. (2004). Metodologi Reseach Jilid 2. Yogyakarta: Andi Publisher

Tim Adiwiyata Tingkat Nasional. (2011). Panduan Adiwiyata Sekolah Peduli dan Berbudaya Lingkungan. Jakarta: Kerjasama Kementerian Lingkungan Hidup dengan Kementerian Pendidikan dan Kebudayaan.

Tim Adiwiyata Tingkat Nasional. (2012). Panduan Adiwiyata Sekolah Peduli dan Berbudaya Linkungan. Jakarta: Kerjasama Kementerian Lingkungan Hidup dengan Kementerian Pendidikan dan Kebudayaan.

Undang-Undang Nomor 32 Tahun 2009 tentang Perlindungan dan Pengelolaan Lingkungan Hidup. Jakarta: Kementerian Lingkungan Hidup.

Undang-Undang Republik Indonesia Nomor 23 Tahun 1997 Tentang Pengelolaan Lingkungan Hidup. Jakarta: Menteri Negara/Sekretaris Negara Republik Indonesia. 